\title{
DISAIN PEMBELAJARAN AUTENTIK BERBASIS SMARTPHONE DENGAN MEMPERHATIKAN KARAKTERISTIK PEBELAJAR DALAM MENINGKATKAN KEMAMPUAN MENULIS, BERKOMUNIKASI, DAN KREATIVITAS
}

\author{
Achmad Noor Fatirul ${ }^{2)}$ dan Djoko Adi Walujo ${ }^{2)}$ \\ ${ }^{1}$ Prodi Teknologi Pendidikan, Sekolah Pascasarjana, Universitas PGRI Adi Buana Surabaya \\ ${ }^{2}$ Prodi Teknologi Industri, Fakultas Teknologi Industri, Universitas PGRI Adi Buana Surabaya \\ Email : 1 anfatirul@gmail.com, adiwalujo@gmail.com ${ }^{2}$
}

\begin{abstract}
Abstrak
Mendisain pembelajaran berorientasi pada hal-hal yang nyatalautentik. Segala sesuatu yang berkaitan dengan informasi/pesan yang akan disampaikan selalu dikaitkan dengan pengalaman nyata dilapangan. Pesan yang akan disampaikan dilakukan dengan tatap muka, dan pemanfaatan media pembelajaran. Media smartphone saat ini sudah bukan menjadi barang mewah lagi dan bahkan merupakan suatu kebutuhan bagi setiap individu. Rancangan pembelajaran ini menggunakan smartphone sebagai alat komunikasi antara pembelajar dan pebelajar, antara pebelajar dengan pebelajar, dan antara pebelajar dengan sumber belajar lainnya. Penelitian ini akan memfasilitasi keinganan pebelajar dalam belajarnya dengan mempertimbangkan karakteristik pebelajar serta kemudahan pebelajar dalam mengikuti proses pembelajaran. Penelitian ini merupakan jenis penelitian pengembangan yang mengacu pada langkah-langkah penelitan pengembangan. Sedangkan langkah-langkah dalam mengembangkan model disain pembelajaran mengacu pada disain pengembangan. Hasil validasi produk didapat bahwa Kemenarikan program sajian model disain pembelajaran bagi pebelajar didapat $90 \%$ mengatakan layak, Relevansi bahan yang dipelajari mengatakan 95\% mengatakan layak, Kebermanfaatan media aplikasi smartphone dan bahan yang dipelajari mengatakan 95\% layak, Kesesuaian bahan yang dipelajari dengan kemudahan akses bahan mengatakan 90\% layak, dan Komunikasi dalam tutorial online oleh pebelajar mengatakan 95\% layak. Kesimpulan yang didapat setelah dilakukan implementasi dilapangan, bahwa produk pembelajaran autentik dapat dipakai oleh dosen dan guru dalam mendisain pembelajaran si sekolah dan perguruan tinggi.
\end{abstract}

Kata Kunci: Disain Pembelajaran Autentik, Karakteristik Pebelajar, Kemampuan Berkomunikasi, Kemampuan Menulis, Kreativitas.

\begin{abstract}
Designing learning is oriented towards real / authentic things. Everything related to information / messages to be conveyed is always associated with real experience in the field. The message to be conveyed is done face-to-face, and the use of learning media. Smartphone media are now no longer a luxury and are a necessity for every individual. This learning design uses a smartphone as a communication tool between learners and students, between students and students, and between students and other learning resources. This research will facilitate the reluctance of students to learn by considering the characteristics of students and the ease of students in following the learning process. This research is a type of development research that refers to the research
\end{abstract}


development steps. While the steps in developing a learning design model refers to the design development. The product validation results obtained that the attractiveness of the program design model of learning design for students obtained $90 \%$ said worthy, Relevance of material learned said 95\% said worthy, Utilization of smartphone application media and learned material said 95\% feasible, Suitability of material learned with easy access to material say $90 \%$ feasible, and Communication in an online tutorial by students says $95 \%$ is feasible. The conclusion obtained after implementation in the field, that authentic learning products can be used by lecturers and teachers in designing learning of schools and colleges.

Keywords: Authentic Learning Design, Student Characteristics, Communication Ability, Writing Ability, Creativity.

\section{PENDAHULUAN}

Kebiasaan yang telah melekat dalam proses pembelajaran selalu tampak dalam kelas yang kaku, materi disajikan dalam bentuk ceramah plus (plus media power point, plus diskusi yang monoton). Kebiasaan ini mendudukkan pebelajar pada posisi individu yang pasif (behavioristik), metode drill (pembiasaan) selalu muncul. Perilaku yang kuat akan muncul apabila reinforcement diberikan dan akan hilang bila dikenai hukuman.

Belajar bukan hanya sekedar aktivitas menulis dipapan tulis atau ceramah dengan konsep mentransfer ilmu belaka, tetapi belajar merupakan petualangan seumur hidup, perjalanan eksplorasi tanpa akhir untuk menciptakan pemahaman personal kita sendiri. Belajar merupakan proses pemaknaan informasi baru dengan jalan mengkaitkan dengan struktur informasi yang telah dimiliki oleh pebelajar. Teori kognitif mendeskripsikan apa yang terjadi dalam diri seseorang ketika individu belajar. Teori kognitif menaruh fokus pada peristiwaperistiwa internal. Penataan kondisi bukanlah sebagai penyebab terjadinya belajar, akan tetapi hanya sekedar bagaimana memudahkan belajar, keaktifan pebelajarlah yang dapat menentukan suksesnya belajar.
Bagaimana cara pebelajar dapat belajar dengan caranya terbaik, sehingga pebelajar dapat tumbuh dan berkembang sesuai potensinya? Permasalahan ini tidak lepas dari potensi pembelajar dalam mendisain pembelajarannya.

Bertolak dari latar belakang permasalahan inilah penelitian ini bertujuan untuk mencari solusi, bagaimana memudahkan pembelajar dalam mengembangkan model disain pembelajaran dengan mudah, tidak rumit, dan memiliki motivasi yang tinggi dalam mendisain pembelajarannya sendiri sesuai dengan karakteristik mata ajar yang diajarkan.

Mendisain pembelajaran berorientasi pada hal-hal yang nyata/autentik, untuk disinergikan dengan struktur informasi yang telah dimiliki oleh pebelajar. Segala sesuatu yang berkaitan dengan informasi/pesan yang akan disampaikan selalu dikaitkan dengan pengalaman-pengalaman atau kejadiankejadian nyata dilapangan akan lebih memberi tantangan pada pebelajar untuk dapat mengetahui lebih banyak tentang apa yang telah diketahuinya bahkan dialaminya. Pesan/informasi yang akan disampaikan tentunya tidak hanya dilakukan dengan tatap muka, akan tetapi dilakukan dengan 
pemanfaatan media pembelajaran. Media komunikasi yang mudah penggunaannya serta menyenangkan dan dapat dilakukan setiap waktu menjadi utama dalam rancangan penelitian ini. Media smartphone saat ini sudah bukan menjadi barang mewah lagi dan bahkan merupakan suatu kebutuhan bagi setiap individu. Rancangan pembelajaran ini menggunakan smartphone sebagai alat komunikasi antara pembelajar dan pebelajar, antara pebelajar dengan pebelajar, dan antara pebelajar dengan sumber belajar lainnya. Penelitian ini akan memfasilitasi keinganan pebelajar dalam belajarnya dengan mempertimbangkan karakteristik pebelajar serta kemudahan pebelajar dalam mengikuti proses pembelajaran, sehingga dalam proses pembelajaran nantinya tidak membosankan melaikan menyenangkan. Karakteristik lain dalam penelitian ini akan dipertimbangkan seperti motivasi berprestasi dan cara belajarnya.

$$
\text { Belajar dengan menyenangkan }
$$

tentunya tidak lepas dari media apa yang tidak menyulitkan pebelajar dalam mengaksesnya. Artinya penyediaan media haruslah dapat memenuhi kebutuhan pebelajar secara perorangan pula. Maraknya perkembangan media internet yang sekarang dapat dikemas tidak hanya di komputer atau laptop, tapi sekarang sudah merambak pada handphone dengan segala kecanggihan aplikasinya. Apapun bentuk media tersebut media pembelajaran merupakan semua sumber yang diperlukan untuk melakukan komunikasi dengan pebelajar (Martin \& Briggs, 1986). Dalam memilih media pembelajaran hendaknya mempertimbangkan bagaimana strategi penyampaian isi pembelajaran kepada pebelajar seperti tingkat interaksi yang mampu ditimbulkannya, tingkat kemampuan yang dimilikinya, tingkat motivasi yang mampu ditimbulkan dan tingkat biaya yang diperlukan.
Hasil survey yang telah dilakukan pada pebelajar, pebelajar telah semua memiliki handphone/smartphone yang memiliki aplikasi seperti WhatApps, Line, Instagram, Messenger, e-mail, dan Facebook. Namun aplikasi tersebut hanya sebagian kecil dipergunakan dalam proses pembelajaran. Dan dalam pemakaian tersebut untuk berkomunikasi hanya pada tingkat yang tidak dikemas secara sistematis dalam proses pembelajaran.

Untuk mengetahui apakah model disin pembelajaran autentik berbantuan aplikasi smartphone ini memiliki ke-efektifan, efisiensi, dan daya tarik pebelajar, sehingga memiliki dampak pada peningkatan kemampuan berkomunikasi, menulis,dan kreativitas, maka akan dilakukan uji coba sebagai implementasi model disain pembelajaran. Dari hasil analisis akan dijadikan buku tentang bagaimana merancang model disan pembelajarannya sendiri sesuai dengan karakteristik mata ajar. Selanjutnya setelah tersusunnya buku ini, maka akan dilaksanakan diklat dan pendampingan dalam menyusun/mendisaian pembelajaran autentik serta bagaimana mendisain pembelajaran yang inovatif dan kreatif.

Berlandaskan pada topik penelitian renstra, pembelajaran yang seharusnya sudah lama diharapkan bagaimana pembelajaran itu inovatif, kreatif, dan menyenangkan serta penerapan kurikulum baru yang belum banyak pembelajar dalam pelaksanaannya. Dari hasil survey, kecenderungan pembelajar dalam mendisain pembelajaran juga banyak dilakukan dengan copy paste dari sejawat yang telah mendisain sebelumnya. Sehingga kenyataan terjadi ketidakmampuan pembelajar dalam mendisain pembelajarannya serta pelaksanaan proses pembelajaran yang masih menggunakan 
metode, strategi lama yang membosankan masih dilakukan.

Penelitian ini bertujuan akan mengembangkan suatu model disain pembelajaran yang inovatif, yang berbasis kemudahan dalam belajar bagi pebelajar, dan memenuhi kebutuhan pebelajar, sehingga model disain pembelajaran tidak membosankan. Sasaran akhir dari model disain pembelajaran adalah buku petunjuk bagaimana mendisain pembelajaran autentik dengan memperhatikan karakteristik pebelajar yang menyenangkan, memudahkan belajar agar timbul perilaku belajar. Selanjutnya penelitian ini dilakukan secara bertahap.

Perangkat pembelajaran tersebut akan di validasi untuk melihat kelayakan dalam mengimplementasi dilapangan. selanjutnya akan dilakukan desiminasi/uji coba produk lingkup terbatas (skala kecil) dan evaluasi serta revisi produk.

Temuan dalam penelitian ini diharapkan adanya model disain pembelajaran berbasis autentik. Proses pembelajaran didisain dengan mempertimbangkan karakteristik pebelajar dengan mengidentifikasi karakteristik dari segi gaya kognitif, motivasi berprestasi, dan cara belajarnya. Dari hasil survey yang telah dilakukan dideskripsikan bahwa temuan dilapangan, pembelajar dalam proses pembelajarannya menggunakan satu model/metode tanpa melihat karakteristik pebelajar, karakteristik mata ajar. Sekalipun menggunakan beberapa metode akan tetapi metode dipakai secara sendiri-sendiri. Metode ceramah dipakai sebagai metode utama yang didampingi dengan penggunaan media power point. Untuk mengetahui kemajuan belajar pebelajar, pembelajar melakukan evaluasi dengan metode lama seperti objektif tes dan subjektif tes. Prinsipprinsip tes yang dianjurkan dalam kurikulum baru tidak terpenuhi. Diskusi kelas yang dilakukan masih dengan model yang monoton, dan setiap kelompok mengerjakan tugas yang sama. Terlihat jelas dalam proses pembelajaran, pembelajar secara umum masih menggunakan cara-cara lama yang membosankan, dan kemampuan dalam mendisain pembelajaran masih minim.

Luaran dalam penelitian ini adalah: (1) Buku tentang bagaimana cara merancang pembelajaran autentik bagi pembelajar (baik guru maupun dosen), Produk dari hasil penelitian ini berjudul "Model Disain Pembelajaran Autentik Berbasis Smartphone" (Perbaikan Kualitas Pembelajaran dengan memperhatikan karakteristik pebelajar yang menyenangkan); (2) Buku modul berbasis autentik pada bidang ajar profesi kependidikan dalam implementasi kelengkapan proses pembelajaran autentik yang merupakan satu paket dengan model disain pembelajaran berbantuan aplikasi smartphone; (3) Blog atau web pembelajar berbasis aplikasi internet yag dapat diakses dengann mudah pada smartphone. Dalam penyimpanan materi dari pembelajar dilakukan dengan beberapa konten yang dapat diakses pebelajar dengan sangat mudah.

\section{KAJIAN LITERATUR}

Dalam memperbaiki kualitas pembelajaran tentunya ditentukan bagaimana disain pembelajaran itu dirancang oleh pembelajar. Dalam penelitian ini, peneliti dalam model disain pembelajaran akan dilandasi dengan teori kognitif yaitu suatu teori yang memandang bahwa proses pembelajaran yang mengaitkan antara pengetahuan baru ke struktur pengetahuan yang telah dimiliki oleh pebelajar. Disain pembelajaran yang baik selalu melibatkan semua variabel yang mempengaruhi belajar. Dalam model disain pembelajaran autentik, 
peneliti mengidentifikasi dan menganalisis tentang semua variabel baik teoritik maupun empirik yang mempengaruhi belajar. Variabel yang mempengaruhi terjadinya perilaku belajar yaitu kondisi pembelajaran, metode pembelajaran, dan hasil belajar (Degeng, 2008). Selanjutnya Degeng menandaskan bahwa kondisi dalam pembelajaran merupakan hal yang mencakup semua variabel yang tidak dapat dimanipulasi oleh perancang dan harus diterima isi pembelajaran, keterbatasan sumber belajar, dan karakteristik pebelajar.

Dalam merancang pembelajaran, hendaknya metode pembelajaran mencakup semua cara yang dipakai untuk mencapai tujuan pembelajaran dalam kondisi tertentu seperti strategi pengorganisasian isi pembelajaran, strategi penyampaian isi pembelajaran, dan strategi mengelola pembelajaran. Hasil pembelajaran mencakup semua akibat yang muncul dari penggunaan metode tertentu, seperti keefektifan, efisiensi, dan daya tarik pembelajaran.

Jadi, inti dalam mendisain pembelajaran adalah bagaimana menetapkan metode pembelajaran yang optimal untuk mencapai hasil pembelajaran yang diinginkan. Dalam mendisain pembelajaran ditekankan pada bagaimana memilih, menetapkan, dan mengembangkan variabel metode pembelajaran. Pemilihan metode pembelajaran harus didasarkan pada anaisis kondisi dan hasil pembelajaran. Analisis akan menunjukkan bagaimana kondisi pembelajarannya dan hasil pembelajaran yang diharapkan, setelah itu baru menetapkan dan mengembangkan pembelajaran dilakukan, jadi langkah penetapan dan mengembangan metode pembelajaran dilakukan setelah pendisain pembelajaran memiliki informasi tentang kondisi nyata yang ada dan hasil pembelajaran yang diharapkan (Suparman.2012).
Model disain pembelajaran autentik penelitian ini akan menggabungkan beberapa strategi yang mendukung dalam pembelajaran autentik sebagai inovasi dalam strategi proses pembelajaran. Pebelajar dalam menyelesaikan tugasnya dapat menginvestigasi jawabannya dengan mengkonstruksi pengetahuan yang telah dimilikinya dari beberapa sumber baik buku dan internet. Dalam menetapkan metode yang optimal, peneliti dalam merancang pembelajaran memegang prinsip bahwa tidak ada metode yang paling unggul untuk semua tujuan maupun kondisi, metode/strategi berbeda memiliki pengaruh yang berbeda dan konsisten pada hasilnya, dan kondisi pembelajaran yag bebeda juga memiliki pengaruh yang konsisten pada hasil pembelajaran.

Model disain pembelajaran autentik dalam penelitian ini secara inti menganut teori kognitif yang konsisten dengan seharusnya dilakukan dalam proses pembelajaran. Dari beberapa teori-teori kognitif dalam mendisain pembelajaran autentik akan mensinergikan teori-teori tersebut menjadi satu kesatuan dengan konsep multimetode. Namun demikian disain yang peneliti kembangkan memperhatikan secara jeli tentang karakteristik pebelajar (gaya kognitif, motivasi berprestasi, dan cara belajar) untuk dijadikan pertimbangan dalam mendisain pembelajaran autentik. Konsep pembelajaran autentik akan mengetrapkan pembelajaran dengan mengedepankan kebutuhan pebelajar dalam belajar. Pertemuan tatap muka di kelas tidak merupakan keharusan untuk dilakukan, melainkan dapat dilakukan diluar kelas sebagai bentuk pembelajaran yang lebih terbuka. Gagne (1985) menyatakan bahwa diperlukan prosess belajar yang lebih terbuka, lebih kondusif terhadap kemandirian dan sikap yang lebih baik terhadap sekolah, 
guru, dan diri sendiri. Dalam konteks ini, dengan belajar secara terbuka pebelajar belajar banyak diruang kelas dengan suasana lebih bebas, dan tidak formal.

Media pembelajaran merupakan semua sumber yang diperlukan dalam melakukan komunikasi dengan pebelajar (Martin \& Briggs, 1986). Dalam memilih media pembelajaran hendaknya dapat mempertimbangkan seberapa tingkat keinteraksian yang ditimbulkan, sebarapa tingkat motivasi yang ditimbulkan dan biaya yang diperlukan. Dalam pemakaian media pembelajaran yang tidak kalah pentingnya juga adalah memperhatikan karakteristik pebelajar. Artinya makin dekat dengan perbedaan karakteristik pebelajar dalam memilih media, maka akan semakin tinggi tingkat motivasi yang akan ditimbukan oleh media tersebut. Heinich, Molenda, \& Russell (1985) dalam Degeng (2008), menyebutkan bahwa "if instructional media are to be used effectively, there mus be a match between the characteristics of learner and the content of the learning material and its presetation".

Interaksi antara pebelajar dengan media merupakan komponen penting dalam mendisain strategi pembelajaran. Disamping Media online yang dipergunakan untuk mengakses informasi dari sumber-sumber, juga dipergunakan untuk berkomunikasi dengan pebelajar lainnya dan pembelajar (Smaldino, Lowther, Russell, 2011). Komputer/laptop memiliki kemampuan untuk menyampaikan informasi apapun, sehingga pebelajar maupun pembelajar dapat mengakses dokumen elektronik untuk memperkaya kajiannya, dan yang paling penting adalah pebelajar dapat berinteraksi dengan belajar online dengan menyediakan lingkungan yang interaktif.

Untuk kepentingan model disain pembelajaran dalam penelitian ini, media akan dikemas menjadi dua katagori yaitu media yang diperuntukkan pebelajar dalam merperkaya kajiannya dalam menyelesaikan tugas-tugasnya yang mudah akses. Sedangkan media yang kedua adalah smartphone dengan aplikasinya. Pebelajar akan diberi kebebasan dalam memakai aplikasi yang disenanginya dan dikuasainya dalam berkomunikasi antar sejawat, dengan pembelajar, atau dengan para pakar atau siapapun yang pebelajar akan bertanya tentang penyelesaian tugas-tugas belajarnya. Aplikasi tersebut akan diapresiasi oleh pembelajar dan pebelajar lainnya untuk ajang diskusi online (tutorial online) yang berupa WhatsApp, Facevbook, Instagram, Blog, Slideshare, dan waktu yang disediakan tentunya setelah pertemuan tatap muka dikelas (tutorial tatap muka). Variabel karakteristik pebelajar dalam penellitian ini, peneliti mengindentifikasinya tentang karateristik gaya kognitif, motivasi berprestasi, dan cara belajar pebelajar.

Gaya Kognitif merupakan salah satu karakteristik pebelajar dalam menerima informasi yaitu tentang bagaimana berfikir dan mengingat informasi dalam memecahkan suatu masalah. Keefe (1987) gaya kognitif pebelajar dalam menerima informasi, sikapnya terhadap informasi, serta kebiasaan berhubungan dengan lingkungan belajarnya. Gaya kognitif ini sifatnya relatif tetap melekat pada pebelajar, sehingga pembelajar dapat merancang strategi dalam memberikan bimbingan terhadap pebelajar. Gaya kognitif para pakar membagi karakteristik ini menjadi gaya kognitif field dependence dan gaya kognitif field independence (Fatirul, 2012). Gaya kognitif field dependence dan gaya kognitif field independence berkenaan dengan persepsi perbedaan antara cara global dan analitik dalam memahami suatu objek dan situasi tertentu (Witkin, 1976).

Untuk mengetahui apakah pebelajar meimiliki gaya kogitif field dependence dan 
gaya kognitif field independence dalam penelitian ini dilakukan dengan menggunakan alat ukur GEFT (Group Emmbedded Figures Tes). Keefe (1987) menyebutkan bahwa individu dalam menerima informasi yang memulai dengan analisis aktif terlebih dahulu disebut dengan individu tersebut memiliki gaya kognitif field dependence, sedangkan individu yang dalam menerima informasi tidak melakukan analisis aktif disebut dengan gaya kognitif field independence. Fritz (1992) juga menyebutkan bahwa individu yang memiliki gaya kognitif field independence akan menggunakan cara berfikir aktif yang mencakup keterampilan menstruktur kognitif, sedangkan individu yang memiliki gaya kognitif field dependence cenderung menggunakan cara berfikirnya pasif dalam kontek belajar.

Penelitian terdahulu tentang gaya kognitif telah banyak dibuktikan bahwa adanya perbedaan antara pebelajar yang memiliki gaya kognnitif field independence dan yaang memiliki gaya kognitif field dependence dan adanya interaksi antara gaya kognitif dengan strategi pembelajaran (Globerson, 1990). Leader \& Klien (1994) dalam penelitiannya menyimpulkan bahwa pebelajara yang meimiliki gaya kognitif field independence secara signifikan nilai post-test nya lebih tinggi dari pada pebelajar yang memiliki gaya kognitif field dependence dalam pencarian data based hipermedia. Ratumanan (2004), hasil belajar lebih baik pebelajar yng memiliki gaya kognitif FI dibandingkan pebelajara yang memiliki gaya kognitif FD.

Prastiti (2006), kemampuan komunikasi matematika dan menyelesaikan soal cerita berbeda secara signifikan antara gaya kognitif field independence (lebih tinggi) dari pada pebelajar yang memiliki gaya kognitif field dependence (lebih rendah). Sahartian (2007), mendapatkan perbedaan prestasi belajar antara kelompok pebelajar FI dan FD, serta juga mendapatkan hasil adanya interaksi antara metodr pembelajaran team assisted individualization versus individual dan gaya kognitif terhadap prestasi belajar. Prestasi belajar pebelajar S1 PGSD dalam mata kuliah belajar dan pembelajaran antara kelompok pebelajar yang memiliki gaya kognitif field dependence dan field independence menunjukkan adanya perbedaan. Prestasi belajar pebelajar yang mempunyai gaya kognitif field independence lebih tinggi dari pebelajaran yang memiliki gaya kognitif field dependence (Fatirul, 2012)

Motivasi Berprestasi adalah keinginan individu dalam mencapai prestasi. Motivasi berprestasi merupakan salah satu karakteristik yang juga melekat pada diri pebelajar. Setiap individu siapapun selalu menginginkan keinginannya mencapai tujuan belajar yang maksimal artinya individu tersebut akan berupaya untuk mendapatkan keiinginannya sesuai standar yang telah ditentukan.

Pebelajar dalam melaksanakan tugas belajarnya dalam mencapai prestasi selalu juga menginginkan memperoleh prestasi belajarnya yang memuaskan. Namun dari setiap pebelajar dengan seala keunikannya kadang memiliki motivasi berpretasi dalam dirinya kuat (motivasi berprestasi tinggi), dan ada pebelajar yang memiliki motivasi berprestasi dalam dirinya rendah.

Pendapat Keller, Kelly, dan Dodge (1978) yang telah dikutip oleh Degeng (2008) ada enam karakteristik motivasi berprestasi yang nampak konsisten ditemukan dalam konteks sekolah yaitu individu yang memiliki motivasi berprestasi tinggi cenderung lebih menyukai terlibat dalam situasi dimana ada resiko gagal artinya individu tersebut menyukai keberhasilan 
akan tetapi dengan suatu tantangan, individu yang memiliki motivasi tinggi akan bekerja keras untuk mencapai keberhasilan terlepas dari hadiah yang akan diberikan ketika berhasil, individu yang bermotivasi tinggi individu cenderung membuat pilihan atau tindakan realistis menyesuaikan dengan tugas-tugas yang yang dikerjakannya, individu yang bermotivasi tinggi akan menilai dan membuat pertimbangan atau membuat keputusannya sendiri, individu yang bermotivasi tinggi juga memiliki perspektif jauh kedepan, dan individu yang bermotivasi tinggi tidak selalu menunjukkan nilai prestasi tinggi karena nilai merupakan dipengaruhi oleh faktor ekstrinsik.

Cara Belajar pebelajar yang dimaksud adalah bagaimana pebelajar belajar tentang materi ajar yang diberikan pembelajar. Cara belajar ini secara eksplisit seperti bagaimana cara pebelajar dalam mengikuti proses pembelajaran, membuat catatan, membuat rangkuman, memperoleh informasi baru yang berkaitan dengan materi ajar yang dipelajariya, mengatur jadwal belajarnya, dan yang tak kalah pentingnya adalah tempat belajar.

Karakteristik pebelajar ini sangat melekat pada diri pebelajar, dan tidak dapat dimanipulasi. Karakteristik pebelajar ini sangat unik, keunikan ini disebabkan karena karakteristik ini melekat pada diri pebelajar. Cara belajar ini sangat berkaitan dengan karakteristik pebelajar gaya kognitif dan motivasi berprestasi pebelajar. Pebelajar yang memiliki gaya belajar field dependent tinggi cenderung dalam mengikuti proses pembelajaran akan mencatat bagian-bagian terpenting saja dibandingkan dengan pebelajar yang memiliki gaya kognitif field dependent yang cenderung dalam mengikuti proses pembelajaran mencatat semua bahan ajar yang diberikan (tanpa memilah-milah bagian-bagian yang penting.
Pebelajar yang memiliki motivasi berprestasi tinggi, cenderung akan selalu mengikuti proses pembelajaran dengan rajin dan lebih sering dibandingkan dengan pebelajar yang memiliki motivasi belajar rendah. Dan yang lebih penting, pebelajar yang memiliki motivasi berprestasi tinggi, cenderung mencari sumber belajar lebih banyak, menyusun catatan perkuliahannya sendiri dan rapih dengan kualitas yang baik. Kecenderungan ini tidak dimiliki oleh pebelajar yang memiliki motivasi berprestasi rendah.

\section{METODE PENELITIAN}

Penelitian ini merupakan jenis penelitian pengembangan yang mengacu pada langkah-langkah penelitan pengembangan Borg \& Gall (2003). Sedangkan langkah-langkah dalam mengembangkan model disain pembelajaran mengacu pada disain pengembangan Dick \& Carey (2001)

\section{HASIL DAN PEMBAHASAN}

Rancangan penelitian ini dilakukan dengan beberapa tahapan-tahapan sebagai berikut: Data yang dikumpulkan melalui penelitian ini berupa penjaringan data tentang: (1) Kemenarikan program sajian model disain pembelajaran bagi pebelajar, (2) Relevansi bahan yang dipelajari, (3) Kebermanfatn media aplikasi smartphone dan bahan yang dipelajari, dan (4) Kesesuaian bahan yang dipelajari dengan kemudahan akses bahan dan (5) Komunikasi dalam tutorial online oleh pebelajar.

Data yang berupa angka diolah/dianalisis dengan menggunakan statistik deskriptif yang penyajiannya dalam bentuk prosentasi. Sedangkan data kualitatif penyajiannya berupa paparan dan eksplanasi data. 
Tabel. 1: Hasil Validasi Produk

\begin{tabular}{|c|c|c|c|}
\hline No & Katagori & $\begin{array}{c}\text { Hasil } \\
\text { Validasi }\end{array}$ & Ket. \\
\hline & \begin{tabular}{lr}
\multicolumn{2}{c}{ Kemenarikan program } \\
sajian model disain \\
pembelajaran \\
pebelajar
\end{tabular} & $90 \%$ & Layak \\
\hline 2. & $\begin{array}{l}\text { Relevansi bahan yang } \\
\text { dipelajari }\end{array}$ & $95 \%$ & Layak \\
\hline & $\begin{array}{l}\text { Kebermanfaatan media } \\
\text { aplikasi smartphone } \\
\text { dan bahan yang } \\
\text { dipelajari }\end{array}$ & $95 \%$ & Layak \\
\hline 4. & $\begin{array}{l}\text { Kesesuaian bahan yang } \\
\text { dipelajari dengan } \\
\text { kemudahan akses bahan }\end{array}$ & $\%$ & Layak \\
\hline 5. & $\begin{array}{l}\text { Komunikasi dalam } \\
\text { tutorial online oleh } \\
\text { pebelajar. }\end{array}$ & $95 \%$ & ayak \\
\hline & $\begin{array}{l}\text { Simpulan yang } \\
\text { kan implementasi di } \\
\text { k pembelajaran auten } \\
\text { dosen dan guru d } \\
\text { elajaran si sekolah } \\
\text {. }\end{array}$ & $\begin{array}{l}\text { dapat } \\
\text { pangan, } \\
\text { d dapat } d \\
\text { am men } \\
\text { dan per }\end{array}$ & $\begin{array}{l}\text { lisain } \\
\text { liruan }\end{array}$ \\
\hline
\end{tabular}

\section{REFERENSI}

Degeng, N.S. 2008, Disain Pembelajaran, Menuju Pribadi Unggul Lewat Perbaikan Kualitas Belajar Mengajar, Teknologi Pembelajaran, Program Pascasarjana, Universitas PGRI Adi Buana Surabaya.

Degeng, N.S. 2008, Media Pembelajaran, Menuju Pribadi Unggul Lewat Perbaikan Kualitas Belajar Mengajar, Teknologi Pembelajaran, Program Pascasarjana, Universitas PGRI Adi Buana Surabaya.
Degeng, N.S. 2008, Karakteristik Mahasiswa, Menuju Pribadi Unggul Lewat Perbaikan Kualitas Belajar Mengajar, Teknologi Pembelajaran, Program Pascasarjana, Universitas PGRI Adi Buana Surabaya.

Dick, W., Carey, L., \& Carey, J.O. 2001. The systematic design of instruction. Fifth Edition, New York: Longman.

Fatirul, A.N., 2012, Pengaruh Strategi Pembelajaran (Problem-Based Learning Berbantuan dan Tanpa Berbantuan Iternet) dan Gaya Kognitif Terhadap Prestasi Belajar. Disertasi. Program Pascasarjana, PPSJ Teknologi Pembelajaran, Universitas Negeri Malang.

Fritz, R.L. 1992. A study of Gender Differences in Cognitive Style and Conative Volition. (online).

Gall, M.D., Gall, J.P., \& Borg, W.R. 2003. Educational Research: An Introduction. Seventh Edition. Boston: Pearson Education, Inc.

Globerson, T. 1990. What's is the Relationship Between Cognitive Style and Cognitive Development? Dalam T. Globerson dan T. Zelniker (Ed) Cognitive Style and Cognitive Development. Norwood. N.J.: Abtex Publishing Corporation.

Gagne, R.M. 1985. The conditions of learning and theory on instruction. New York: CBS Colledge Publishing.

Heinich, R., Molenda, M., Russell, J.D. \& Smaldino, S.E., 2001, Instructional Media and technologies for Learning. Upper Saddle River, NJ: Pearson Education, Inc.

Keefe, J.W., 1987. Learning Style Theory and Practice. Virginia: National Association of Secondary School Principles 
Leader, L.F., \& Klien, J.D. 1994. The Effect of Search Tool and Cognitive Style on Performance in Hypermedia Database Searches.

(Online). (http://eric.ed.gov/ERICDoes/data/eric doc2sq1/content storege 01/0000019b 180/13/4c/03.pdf.) , diakses 20 Juni 2017.

Martin, R.M., Briggs, L.J., 1986. The Affective and Cognitive Domains: Integration for Instruction and Research. Englewood Cliffs, N.J.: Educational Technology Publications.

Prastiti, T.D. 2006. Pengaruh Pendekatan Pembelajaran Matematika dan Gaya Kognitif Siswa Terhadap Kemampuan Komunikasi Matematika dan Penyelesaian Soal Cerita Bagi Siswa Kelas 1 SLTP. Disertasi, tidak diterbitkan. Malang Program Pascasarjana Universitas Negeri Malang.

Ratumanan, T.G. 2004. Pengaruh Model Pembelajaran dan Gaya Kognitif Terhadap Hasil Belajar Matematika Siswa SLTP di Kota Ambon. Jurnal Pendidikan Dasar, 5(1): 1-10.

Sahertian, C.J.W. 2007. Pengaruh Metode Pembelajaran TAI vs Individual dan Gaya Kognitif Terhadap Prestasi Belajar Pada Mata Kuliah Evaluasi Pendidikan Agama Kristen Mahasiswa STAKPN Ambon. Disertasi, tidak diterbitkan. Malang: Program Pascasarjana Universitas Negeri Malang.

Smaldino, E.S., Lowther, D.L., Russell, J.D., 2011. Instructional Technology \& Media for Learning, Teknologi Pembelajaran dan Media untuk Belajar, Kencana Prenada Media Grup, Jakarta.

Suparman, A. M., 2012, Desain Instruksional Modern, Panduan Para Pengajar dan
Inovator Pendidikan, penerbit: Erlangga, Jakarta.

Witkin, H.A. 1976. Cognitive Style Academic Performance and in Teacher Student Relation, Dalam Messich, (ed). Individually in Learning. San Francisco: Jossey Bass. 